\title{
Study on the Effects of Extraction and Purification Conditions on the Activity of Peroxidase and Polyphenol Oxidase from Chestnut Kernel and on Their Substrates
}

\author{
Zhang Xingyuan ${ }_{1,2}^{1,2}$, Han Mengmeng ${ }^{1,2}$, Cai Ziyi ${ }^{1,2}$, Gao Xiang ${ }^{1,2}$, Wang Fang ${ }^{1,2,3}$, Pang Meixia ${ }^{1,2,3}$, \\ Qi Jinghua ${ }^{1,2,3 \text {, * }}$ \\ ${ }^{1}$ Beijing Key Laboratory of Agricultural, Product Detection and Control of Spoilage Organisms and Pesticide Residue, Beijing University of \\ Agriculture, Beijing, China \\ ${ }^{2}$ The Teaching Group of Food Chemistry, Faculty of Food Science and Engineering, Beijing University of Agriculture, Beijing, China \\ ${ }^{3}$ Beijing Innovation Consortium of Swine Research System, Beijing, China
}

Email address:

1846162664@qq.com (Zhang Xingyuan), abc960718@sina.com (Qi Jinghua)

${ }^{*}$ Corresponding author

\section{To cite this article:}

Zhang Xingyuan, Han Mengmeng, Cai Ziyi, Gao Xiang, Wang Fang, Pang Meixia, Qi Jinghua. Study on the Effects of Extraction and Purification Conditions on the Activity of Peroxidase and Polyphenol Oxidase from Chestnut Kernel and on Their Substrates. American Journal of Bioscience and Bioengineering. Vol. 7, No. 2, 2019, pp. 40-45. doi: 10.11648/j.bio.20190702.13

Received: April 15, 2019; Accepted: May 26, 2019; Published: June 15, 2019

\begin{abstract}
Chestnut kernel is a woody grain with high nutritional value and utilized value, but it is susceptible to Browning. Previous studies have shown that phenol is the substrate of enzymes that lead to browning. In order to investigate the substrates that that leads to browning of peroxidase (POD) and polyphenol oxidase (PPO) of chestnut kernel. The extraction and purification methods and the main substrates of POD and PPO from chestnut kernel were investigated. First, the effects on enzyme activity of different kinds of buffer, temperature, time and $\mathrm{pH}$ value were studied; second, the salting out purification of different concentrations and the main substrates of POD and PPO from chestnut were studied. The results were shown that POD enzyme in chestnut could be obtained by extracting with sodium dihydrogen phosphate-dibasic sodium phosphate buffer $(\mathrm{pH} 6.8)$ at $4^{\circ} \mathrm{C}$ for $5 \mathrm{~h}$. PPO enzyme in chestnut could be obtained by extracting with disodium hydrogen phosphate-citric acid buffer ( $\mathrm{pH} 5.4$ ) at $4^{\circ} \mathrm{C}$ for $5 \mathrm{~h}$. The two enzymes could be purified best by $80 \%$ ammonium sulfate, and the activity of POD and PPO enzyme had been enhanced for $60 \%$ and $190 \%$ respectively. Gallic acid might be the main substrate of POD and PPO in browning of chestnut kernel.
\end{abstract}

Keywords: Chestnut Kernel, Enzymatic Browning, Extraction, Purification, Substrate

\section{Introduction}

Chestnut is the general name of the trees or shrubs of chestnut genus in the beech family. It is widely distributed in Europe, South America, North America, Africa and Asia [1]. Chinese chestnut has a long history of planting in China, rich in nutrition and high starch content, is a kind of woody food, known as "the king of dried fruit" [2]. However, Browning is trend to occur in chestnut processing. There are two types of browning related to chestnut, namely non-enzymatic browning and enzymatic browning. Studies have confirmed that phenolic substances in chestnut are oxidated by polyphenol oxidase
(PPO) and Peroxidase (POD) to become black-brown substances [3]. Many scholars have studied how to control the enzymatic browning of chestnut [4]. For example, the pretreatment methods of quenching enzyme in the processing of sugaring-chestnut had been studied by Zeng Tingting [5], and the results showed that microwave blanching was better than steam blanching and water blanching in inhibiting the browning of the chestnut and increasing the efficiency of sugared infiltration. However, presently there is very little information about the substrates of PPO and POD from chestnut kernel. Therefore, the extraction and purification methods of POD and PPO enzymes from chestnut kernel and their main substrates were optimized in this study. 


\section{Materials and Methods}

\subsection{Extraction of Crude Enzyme Solution}

The chestnut was removed from the shell and washed by distilled water, then pulverized. First, $5 \mathrm{~g}$ chestnut powder was put into a centrifuge tube, and added $20 \mathrm{~mL}$ of precooled buffer to homogenize the mixture. The mixture was extracted at certain temperature for an appropriate time, then centrifugated $(10000 \mathrm{r} / \mathrm{min})$ at low temperatures for $10 \mathrm{~min}$. The supernatant was the crude enzyme solution of POD. [6]

$15 \mathrm{~g}$ fresh chestnut was peeled in mortar, and cryogenically comminuted. With $100 \mathrm{~mL}$ pre-cooled buffer (containing 3\% PVPP, $10 \% \mathrm{NaCl}$ ) added, chestnut powder was extracted. Then the extract was collected at $4{ }^{\circ} \mathrm{C}$, and centrifugated $(10000 \mathrm{r} / \mathrm{min})$ at low temperatures for $10 \mathrm{~min}$. The supernatant was the crude enzyme solution of PPO. [7]

\subsection{Extraction of Chestnut Phenolic Substrates}

The fresh chestnut was shelled, and crushed after chilled by liquid nitrogen. Using $60 \%$ acetone solution, the chestnut powder was extracted (the material-liquid ratio was 1:5) by ultrasonic method at $4{ }^{\circ} \mathrm{C}$ for $60 \mathrm{~min}$. The crude extract was obtained after filtrating, centrifuging and concentrating at vacuum. The crude extract was placed on a polyamide column (the speed and concentration of sample loading were $1.4 \mathrm{~mL} / \mathrm{min}$ and $0.0306 \mathrm{mg} / \mathrm{mL}$, respectively). First, $30 \%$ ethanol was used for eluting, continuing to elute with $60 \%$ ethanol when the elution volume of $30 \%$ ethanol reached to $150 \mathrm{~mL}$. The component eluted by $30 \%$ ethanol (the component had been proved was gallic acid when determined by scanning with UV spectrum and high performance liquid chromatography) and the component eluted by $60 \%$ ethanol were obtained (the component were gallic acid, ferulic acid and catechin when determined by scanning with UV spectrum and high performance liquid chromatography). [8]

\subsection{Activity for Determining POD and PPO}

$50 \mathrm{~mL} 0.05 \mathrm{~mol} / \mathrm{L}$ phosphate buffer ( $\mathrm{pH}$ 6.0) was taken into a beaker, and added $28 \mu \mathrm{L}$ guaiacol, mixed, then added $19 \mu \mathrm{L}$ $30 \%$ hydrogen peroxide after the solution was cooled, mixed evenly, finally stored in refrigerator. Two cuvettes $(1 \mathrm{~cm})$ were taken, and the first one was added with $3 \mathrm{~mL}$ of the reaction mixture and $1 \mathrm{~mL}$ of the phosphoric buffer ( $\mathrm{pH}$ 6.8) as the blank control. In the other, $3 \mathrm{~mL}$ of the reaction mixture and 1 $\mathrm{mL}$ of POD's solution (if the enzyme activity was too high to measure, it could be diluted) were added. In order to make sure the accuracy of the absorbance the stopwatch must be turned on immediately to record time. At the same time the $\mathrm{A}_{470}$ was measured per minute. [9] Peroxidase activity (U) was expressed as 1 activity unit when $\mathrm{A}_{470}$ change for 0.01 per minute. The calculation formula is as follows:

$$
\mathrm{POD} / \mathrm{U}=\Delta \mathrm{A}_{470} \times \mathrm{V}_{\mathrm{T}} / \mathrm{W} \times \mathrm{V}_{\mathrm{S}} \times 0.01 \times \mathrm{t}[\mathrm{u} /(\mathrm{g} \cdot \mathrm{min})]
$$

Note: $\Delta \mathrm{A}_{470}$ was the change of absorbance during the reaction time; $\mathrm{V}_{\mathrm{T}}$ was the total volume of enzyme solution / $\mathrm{mL}$; W was the weight of the sample / $\mathrm{g} ; \mathrm{V}_{\mathrm{S}}$ was the enzyme liquid volume at the time of determination $/ \mathrm{mL}$; $\mathrm{t}$ was the reaction time / $\mathrm{min}$;

$1.5 \mathrm{~mL}$ phosphate buffer was taken into a centrifuge tube $(10 \mathrm{~mL})$, and added $1 \mathrm{~mL} 0.1 \mathrm{~mol} / \mathrm{L}$ catechol that preserved at $35^{\circ} \mathrm{C}$ for $3 \mathrm{~min}$ in advance, and then added $0.5 \mathrm{~mL}$ PPO crude enzyme, mixed, finally measured absorbance at 420 $\mathrm{nm}$. Once adding the enzyme solution, the absorbance value was recorded instantly every $30 \mathrm{~s}$. The enzyme activity was calculated based on the slope of the initial straight line. The amount of enzyme, under test conditions, that caused change for 0.01 of absorbance per minute is defined as one unit of enzyme activity [10-11] which was expressed by U. The calculation formula is as follows:

$$
\mathrm{PPO} / \mathrm{U}=\Delta \mathrm{A}_{420} \times \mathrm{V}_{\mathrm{t}} \times \mathrm{t} /\left(\mathrm{V}_{\mathrm{S}} \times \mathrm{W} \times 0.01\right)
$$

Note: $\Delta \mathrm{A}_{420}$ was the change of absorbance during the reaction time; $V_{t}$ was the total volume of extract enzyme solution / $\mathrm{mL}$; $\mathrm{t}$ was the reaction time / $\mathrm{min}$; $\mathrm{V}_{\mathrm{S}}$ was the enzyme liquid volume at the time of determination / $\mathrm{mL}$; W was the weight of the sample / $\mathrm{g}$;

\subsection{Optimization of POD and PPO}

Optimization of POD: Disodium hydrogen phosphate-sodium dihydrogen phosphate $(\mathrm{pH}$ 6.8) and dipotassium hydrogen phosphate-potassium dihydrogen phosphate $(\mathrm{pH} 6.8)$ were selected respectively as buffer, then the crude enzyme was extracted at $5^{\circ} \mathrm{C}$ for $4 \mathrm{~h}$. Experiments were repeated by three times. $0^{\circ} \mathrm{C}, 4^{\circ} \mathrm{C}, 8^{\circ} \mathrm{C}, 12^{\circ} \mathrm{C}, 16^{\circ} \mathrm{C}$, $20^{\circ} \mathrm{C}$ and $24^{\circ} \mathrm{C}$ were selected respectively as extraction temperature. Disodium hydrogen phosphate-sodium dihydrogen phosphate $(\mathrm{pH}$ 7.2) was selected as buffer to extract for $4 \mathrm{~h}$, then the crude enzyme would be obtained. Experiments were repeated by three times. $2 \mathrm{~h}, 3 \mathrm{~h}, 4 \mathrm{~h}, 5 \mathrm{~h}$ and $6 \mathrm{~h}$ were selected respectively as extraction time, Disodium hydrogen phosphate-sodium dihydrogen phosphate (pH7.2) was selected as buffer to extract at $4^{\circ} \mathrm{C}$, then the crude enzyme would be obtained. Experiments were repeated by three times. Different $\mathrm{pH}$ value of disodium hydrogen phosphate-sodium dihydrogen phosphate in 6.0, 6.4, 6.8, 7.2, 7.6 and 8.0 were selected respectively to extract crude enzyme at $4^{\circ} \mathrm{C}$ for $5 \mathrm{~h}$. Experiments were repeated by three times. [12]

Optimization of PPO: Disodium hydrogen phosphate-citric acid ( $\mathrm{pH}$ 5.4) and sodium citrate-citric acid ( $\mathrm{pH}$ 5.4) were selected respectively as buffer, then the crude enzyme was extracted at $4^{\circ} \mathrm{C}$ for $4 \mathrm{~h}$. Experiments were repeated by three times. $0^{\circ} \mathrm{C}, 4^{\circ} \mathrm{C}, 8^{\circ} \mathrm{C}, 12^{\circ} \mathrm{C}, 16^{\circ} \mathrm{C}, 20^{\circ} \mathrm{C}$ and $24^{\circ} \mathrm{C}$ were selected respectively as extraction temperature. Sodium citrate-citric acid ( $\mathrm{pH}$ 5.4) was selected as buffer to extract for $4 \mathrm{~h}$, then the crude enzyme would be obtained. Experiments were repeated by three times. $1 \mathrm{~h}, 2 \mathrm{~h}, 3 \mathrm{~h}, 4 \mathrm{~h}$, $5 \mathrm{~h}, 6 \mathrm{~h}, 7 \mathrm{~h}$ and $8 \mathrm{~h}$ were selected respectively as extraction time, sodium citrate-citric acid $(\mathrm{pH}$ 5.4) was selected as buffer to extract at $4^{\circ} \mathrm{C}$, then the crude enzyme would be obtained. Experiments were repeated by three times. Different $\mathrm{pH}$ value of sodium citrate-citric acid in 4.6, 5.0, $5.4,5.8$ and 6.2 were selected respectively to extract crude 
enzyme at $4^{\circ} \mathrm{C}$ for $4 \mathrm{~h}$. Calculate the enzyme activity extracted. Experiments were repeated by three times. [12]

\subsection{Purification of POD and PPO}

Purification of POD enzyme: Solid ammonium sulfate was added to the crude enzyme until the saturation reach to $40 \%$, then removed the impurities. Keep on added the solid ammonium sulfate until the saturation reach to $50 \%, 60 \%$, $70 \%, 80 \%$ and $90 \%$ respectively. Then the solution was stood for $30 \mathrm{~min}$, and centrifuged $(10000 \mathrm{r} / \mathrm{min})$ at freeze for 30 min. The precipitation that discarded supernatant was dissolved in phosphate buffer $(\mathrm{pH}$ 6.8), then centrifuged $(6000 \mathrm{r} / \mathrm{min})$ at freeze for $40 \mathrm{~min}$. The supernatant collected was dialyzed with buffer at $4^{\circ} \mathrm{C}$ for $24 \mathrm{~h}$, then the POD enzyme preliminary purified could be obtained. Experiments were repeated by three times. [7]

Purification of PPO enzyme: Solid ammonium sulfate was added to the crude enzyme until the saturation reach to $30 \%$, then removed the impurities. Keep on added the solid ammonium sulfate until the saturation reach to $50 \%, 60 \%$, $70 \%, 80 \%$ and $90 \%$ respectively. Then the solution was stood for $10 \mathrm{~min}$, and centrifuged $(10000 \mathrm{r} / \mathrm{min})$ at $4^{\circ} \mathrm{C}$ for $10 \mathrm{~min}$. The precipitate obtained was dissolved with a small amount of buffer ( $\mathrm{pH}$ 5.4), then the POD enzyme preliminary purified could be obtained. Experiment must be repeated three times. [7]

\subsection{Substrates of POD and PPO}

The purified POD enzyme was reacted with endogenous substrates (30\% ethanol eluate and 60\% ethanol eluate) and exogenous substrates (gallic acid, ferulic acid, catechin) respectively of the condition of $30^{\circ} \mathrm{C}$ and $\mathrm{pH} 4.5$. The optimal substrate of POD enzyme in chestnut could be determined by measuring enzyme activity. [8]

The purified PPO enzyme was reacted with endogenous substrates (30\% ethanol eluate and 60\% ethanol eluate) and exogenous substrates (gallic acid, ferulic acid, catechin) respectively of the condition of $25^{\circ} \mathrm{C}$ and $\mathrm{pH}$ 5.8. The optimal substrate of PPO enzyme in chestnut could be determined by measuring enzyme activity. [8]

\section{Results and Discussion}

The use of buffer to maintain a suitable $\mathrm{pH}$ valve during extraction of POD enzyme is good for increase the activity of enzyme. The activity of enzyme is be affected by different metal ions. It could be seen from Figure 1 that the activity of the POD enzyme was always higher when disodium hydrogen phosphate-sodium dihydrogen phosphate was used as extraction buffer than dipotassium hydrogen phosphate-potassium dihydrogen phosphate. The results were shown that the POD enzyme activity could be protected better by phosphate buffer of sodium than of potassium.

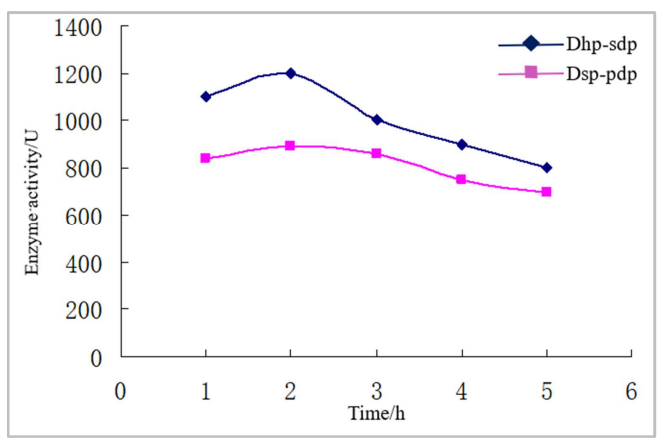

Figure 1. Effect of different buffer extracts on POD enzyme activities in chestnut.

Notes: Dhp-sdp is Disodium hydrogen phosphate-sodium dihydrogen phosphate; Dhp-pdp is Dipotassium hydrogen phosphate-potassium dihydrogen phosphate.

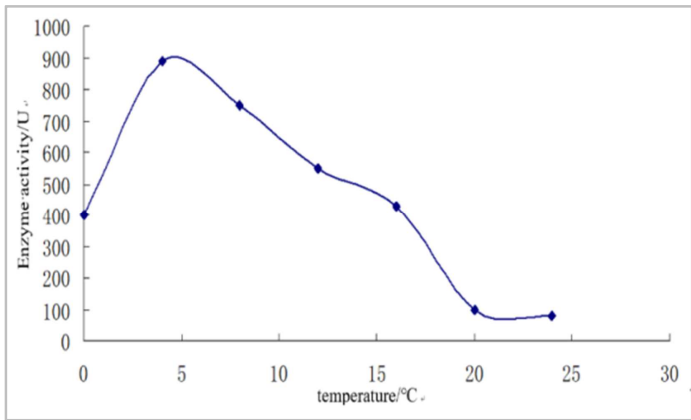

Figure 2. Effect of different extraction temperatures on POD enzyme activities.

It could be seen from Figure 3 that the POD enzyme activity increased gradually with the increase of extract temperature, and peaked in $4^{\circ} \mathrm{C}$ at $900 \mathrm{U}$. After that declined gradually, then leveled off after $20^{\circ} \mathrm{C}$. This indicated that the POD enzyme of chestnut had poor thermal stability easily by inactivated when placed at room temperature. So, in order to protect the enzyme activity it should be extracted at low temperature. According to the results, the best extraction temperature was $4^{\circ} \mathrm{C}$.

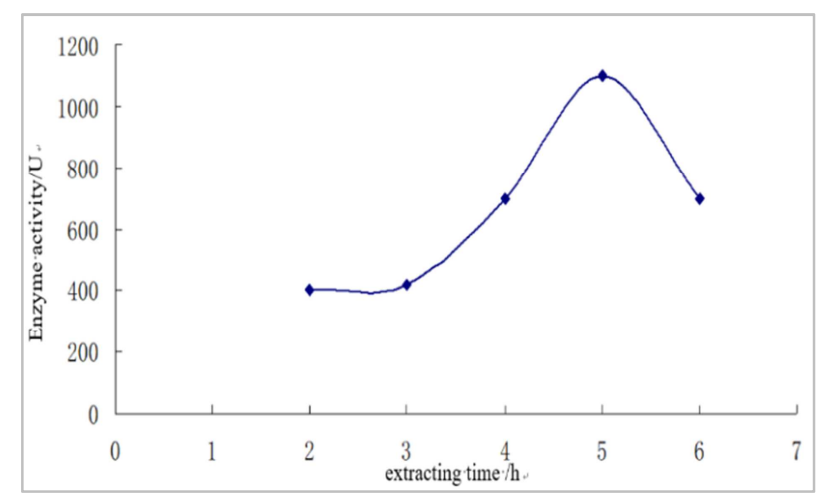

Figure 3. Effect of extraction time on POD enzyme activity.

It can be ensured that the POD of chestnut could be leached completely if choosing sufficient leaching time. It could be seen from Figure 5 that the enzyme activity of POD enzyme in chestnut could reach to $100 \%$ when the extraction 
time was $5 \mathrm{~h}$, and the activity of the enzyme were $73.3 \%$ and $66.7 \%$ respectively at the $6 \mathrm{~h}$ and $3 \mathrm{~h}$. The extraction time was too short or too long both to fully extract the peroxidase.

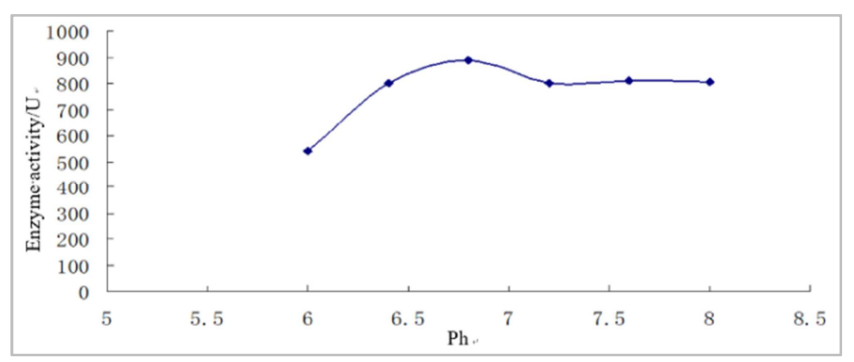

Figure 4. Effect of different extraction $\mathrm{pH}$ on $P O D$ enzyme activity.

The essence of enzymes are protein so that its spatial structure will be destroyed and its activity level be suppressed if the $\mathrm{pH}$ environment is too high or low. It could be seen from Figure 6 that the enzyme activity was the highest when the environment condition of extract was $\mathrm{pH}$ 6.8 , which indicating that the optimal $\mathrm{pH}$ value of POD enzyme extraction was 6.8 . The stability of POD in chestnut was higher under neutral and alkalescence conditions, while decreases rapidly with the decrease of $\mathrm{pH}$ under acidic conditions. This was because the structure of the enzyme is relatively stable under alkaline conditions, and its activity was suppressed [13]. In summary, the POD of chestnut should be extracted at $\mathrm{pH} 6.8$.

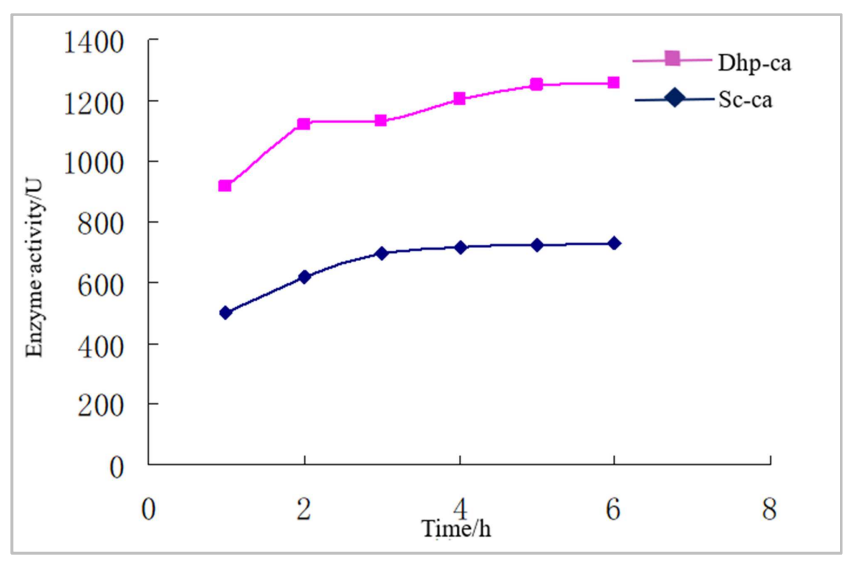

Figure 5. Effect of different buffer extracts on PPO enzyme activities in chestnut.

Notes: Dhp-ca is Disodium hydrogen phosphate-citric acid; Sc-ca is Sodium citrate-citric acid.

It could be seen from Figure 2 that the enzyme activity when disodium hydrogen phosphate-sodium citrate was used as buffer was twice than sodium citrate-citric acid under the same conditions. This may be due to the enzyme activity is suppressed more obvious by citric acid than phosphoric acid, so that the enzyme activity is more active when extracted with phosphate buffer. Therefore, disodium hydrogen phosphate-citric acid ( $\mathrm{pH}$ 5.4) was chosen as buffer to extract crude enzyme.

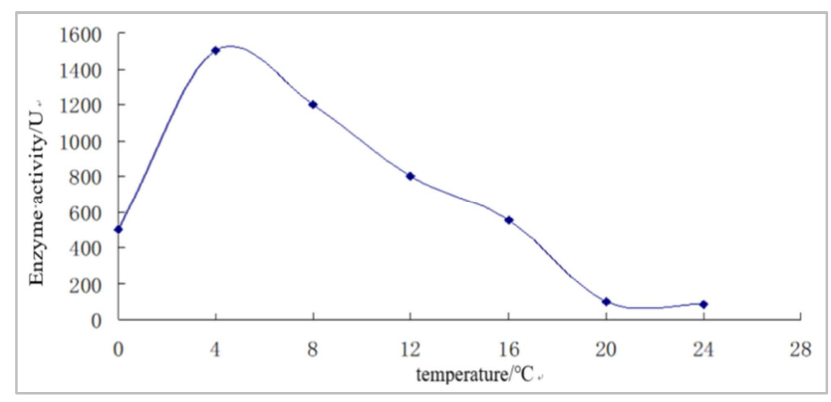

Figure 6. Effect of different extraction temperatures on PPO enzyme activities.

Just like the POD, the enzyme activity of PPO increased gradually with the increase of temperature, and peaked in $4^{\circ} \mathrm{C}$ at $1515 \mathrm{U}$, after that declined gradually, then leveled off after $20^{\circ} \mathrm{C}$. The $\mathrm{PPO}$ was sensitive to heat, it maybe degenerated and inactivated if placed in room temperature of $25^{\circ} \mathrm{C}$ for a long time, thus $4{ }^{\circ} \mathrm{C}$ should be selected for extraction temperature

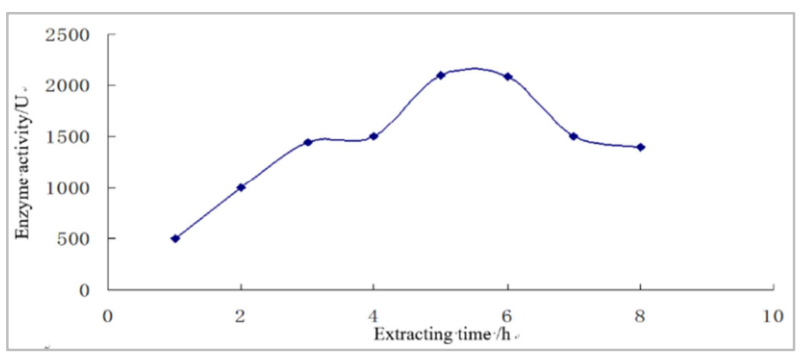

Figure 7. Effect of extraction time on PPO enzyme activity.

It could be seen from Figure 6 that the activity of the PPO enzyme in the crude enzyme extracted for $5 \mathrm{~h}$ and $6 \mathrm{~h}$ were both larger than other time, and the activity of the crude enzyme obtained at $6 \mathrm{~h}$ was only 1.03 times than at $5 \mathrm{~h}$. The enzyme activity was decreased gradually when the leaching time exceeds $6 \mathrm{~h}$, therefore the extraction effect would not be so good if the extraction time was too long, which may cause the enzyme to be inactivated. Considering the extraction effect and economic benefit comprehensively, $5 \mathrm{~h}$ was the best.

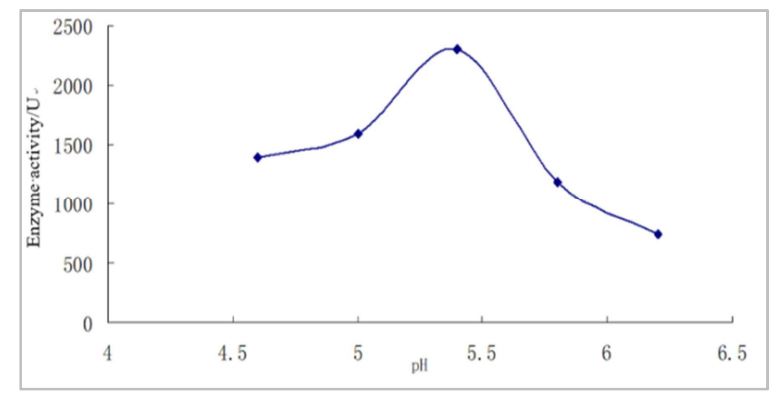

Figure 8. Effect of different extraction $p H$ on PPO enzyme activity.

It could be seen from Figure 8 that the PPO enzyme activity of chestnut was decreased slowly and then decreased rapidly in the range of $\mathrm{pH} 4.6$ to $\mathrm{pH} 6.2$, and peaked in $\mathrm{pH}$ 5.4 at $2300 \mathrm{U}$. In $\mathrm{pH} 6.2$, the $\mathrm{pH}$ was dropped to $780 \mathrm{U}$. Indicated that the PPO enzyme in chestnut could stabilize for 
a long time at acidic environment, and more suitable to extract at acidic conditions. The PPO enzyme would be inactivated if the $\mathrm{pH}$ was greater than 6.0 , so it should be extracted at $\mathrm{pH} 5.4$.

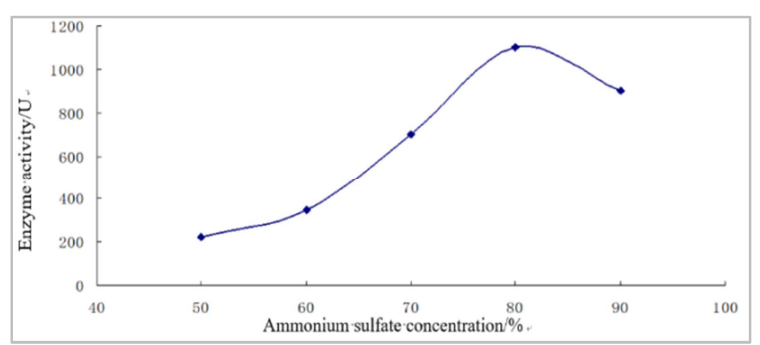

Figure 9. Effect of salting out of different ammonium sulfate concentrations on POD enzyme activities

Salting out is defined as the phenomenon that proteins precipitate with the increase of salt concentration when neutral salts are added to aqueous solutions of proteins. The principle is that in the protein solution with high concentration of salt ions would compete with proteins for water molecules, result in the hydration membrane of surface been damaged, the solubility is reduced and the protein is precipitated out of the solution. Common neutral salts include ammonium sulfate, sodium chloride, sodium sulfate and so on, but ammonium sulfate is the most commonly used. It is widely used in the separation, concentration, storage and purification of proteins because of its high solubility, small temperature coefficient and difficulty in denaturing proteins [14-15]. The ammonium sulfate precipitation grading method was used to purify POD enzyme of chestnut in this test, and the enzyme activity was used as norm. It could be seen from
Figure 9 that ammonium sulfate concentration had a significant difference in the enzyme activity. The enzyme activity was the highest when ammonium sulfate saturation was $80 \%$, indicating that the optimal saturation of POD in chestnut was $80 \%$ when ammonium sulfate was added for second time. The POD could not be purified completely, regardless of the saturation of ammonium sulfate was less than or more than $80 \%$. After grade precipitating by $80 \%$ ammonium sulfate the activity of POD had enhanced $60 \%$.

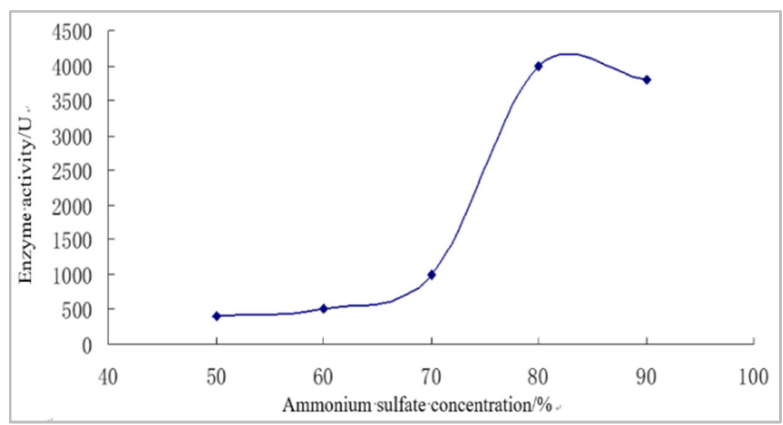

Figure 10. Effect of salting out of different ammonium sulfate concentrations on PPO enzyme activities.

It could be seen from Figure 10 that the PPO activities of chestnut were not significant different after with ammonium sulfate salting at 50\% 70\% saturation, and the activities were all low. The PPO enzyme activity had been enhanced $190 \%$ after purifying by $80 \%$ ammonium sulfate. The enzyme activity showed a downtrend when the saturation of ammonium sulfate continued to increase to $90 \%$, so the PPO enzyme could be precipitated effectively by $80 \%$ ammonium sulfate.

Table 1. Enzyme activity of POD and PPO in reaction with different internal and external substrates.

\begin{tabular}{llll}
\hline Substrate & & POD enzyme reaction enzyme activity (U) & PPO enzyme reaction enzyme activity (U) \\
\hline \multirow{2}{*}{ Endogenous substrate } & $30 \%$ ethanol elution component & 733 & 2320 \\
& $60 \%$ ethanol elution component & 640 & 1523 \\
& Gallic acid & 3573 & 5306 \\
Exogenous substrate & Ferulic acid & 2293 & 18 \\
& Catechin & 2026 & 1200 \\
\hline
\end{tabular}

It could be seen from Table 1 that $30 \%$ and $60 \%$ ethanol eluting components were both substrates of POD and PPO enzymes of chestnut. Gallic acid, ferulic acid and catechin might be substrates of POD and PPO enzymes. However, the activity of POD reacted with endogenous substrates was significantly lower than with exogenous substrates, and the activity reacted with gallic acid was the highest reached 3573 U. Ferulic acid and catechin could also react with POD, but the activity was lower than with Gallic acid. Accordingly, it could be inferred that the substrate reacted with POD enzyme in chestnut contained gallic acid, ferulic acid and catechin, and the gallic acid might be the main substrate for browning reaction. The enzyme activity was relatively higher when PPO enzyme in chestnut reacted with $30 \%$ ethanol elution fraction than $60 \%$ ethanol elution. It could be discovered from Table 1 that the activity was the highest when PPO enzyme in chestnut reacted with gallic acid. Catechin and ferulic acid both could react with PPO enzyme in chestnut, but the activity was significantly lower than gallic acid. The activity that PPO enzyme reacted with ferulic acid was the lowest. It is concluded that the substrates lead to the enzymatic browning in chestnut contained gallic acid and catechin, and the most important substrate might be gallic acid.

\section{Conclusion}

POD in chestnut could be obtained by extracting with sodium dihydrogen phosphate-dibasic sodium phosphate buffer ( $\mathrm{pH} \mathrm{6.8)}$ at $4^{\circ} \mathrm{C}$ for $5 \mathrm{~h}, \mathrm{PPO}$ in chestnut could be obtained by extracting with disodium hydrogen phosphate-citric acid buffer ( $\mathrm{pH} 5.4$ ) at $4{ }^{\circ} \mathrm{C}$ for $5 \mathrm{~h}$. Those two enzymes could be purified by $80 \%$ ammonium sulfate, and the activity of POD had enhanced $60 \%$, the PPO enzyme 
had enhanced $190 \%$. It was found that gallic acid may be the main substrate for browning of chestnut kernel.

\section{Acknowledgements}

We thank The Teaching Group of Food Chemistry, Faculty of Food Science and Engineering of Beijing University of Agriculture for laboratory assistance. Molecular analyses were supported by Beijing Key Laboratory of Agricultural, Product Detection and Control of Spoilage Organisms and Pesticide Residue. We thank Beijing Innovation Consortium of Swine Research System and Graduation Design of the Practical Training Program for the Cross-Cultivation of High-Level Talents in Beijing Colleges and Universities for support.

\section{References}

[1] Luo Chunfang. Study on EndoPhytic Fungi Resources And Biological Control Dry-rot Bacteria of Chestnut [D]. Xinyang Normal University, 2010.

[2] Song Guangsen. The development and multi-utilization of the chestnut resources [J]. Cereal \& Food Industry, 2001 (3): 16-19.

[3] Dong Cui. Research Progress on Browning of Chestnut [J]. Anhui Agricultural Science Bulletin, 2016, 22 (15): 118-120.

[4] Geng Jiannuan. Analyse of Browning Factors during the Process of Chinese Chestnut [J]. Hubei Agricultural Sciences, 2014, 53 (08): 1879-1881.

[5] ZENG Ting-ting, ZHANG Li-yan, RUI Han-ming. Study on enzymatic browning and blanching methods of chestnut [J]. Science and Technology of Food Industry, 2011, 32 (10): $110-113$.

[6] Chen Yalan, Wang Qing, Zhang Jian. Physical Activity of Transgenic Homozygous Triploid of Potatoes [J]. Chinese Potato Journal 2005, (1) 2000, (1): 24 25.
[7] Sun Jian. Studies on the major substrates for polyphenol oxidases in pericarp tissues of litchi fruit [D]. Graduate University of Chinese Academy of Sciences PhD thesis, 2008.

[8] Wang Jing, Qing Jinhua, Wu Yihong, et al. Study on the Factors that Related to Enzymatic Browning from the Castanea mollissima Blume Kernel [J]. Chinese Agricultural Science Bulletin, 2010, 26 (20): 73-79.

[9] Department of Physiology, Department of Biology, East China Normal University. Plant Physiology Experiment Guide [M]. People's Education Press. 1980: 143 144.

[10] Tian S P, Xu Y, Jiang A L, et al. Changes in enzymatic activity and quality attributes of 1ate-mature peaches in response to controlled atmosphere conductions [J]. Agric Science in China, 2002, 1: 207 212.

[11] Anderson J V, Fuerst P E, Hurkman W J, et al. Biochemical and genetic characterization of wheat (Tritcum spp.) kernel polyphenol oxidases [J]. Journal of Cereal Science, 2006, 44 (3): $353-367$.

[12] Liu Xiaoyang, Li Ling, Gao Guizhen. Influence of Light Intensity on POD, PAL and PPO Activity of Pyrus bretschneideri cv. Dangshan Su Fruit in Its Growth Phase [J]. Acta Laser Biology Sinica, 2008, (3): 39 53.

[13] Wu ZX. Studies on the Enzymes that Related to cell wall Metabolism and Pericarp Browning in Longan [A]. Chinese Society for Horticultural Science. The Collected Papers of 7 th Youth Symposium on Chinese Society for Horticultural Science [C]. Chinese Society for Horticultural Science: Chinese Society for Horticultural Science, 2006: 5.

[14] Mao Linchun. Technical problems and countermeasures of chestnut processing [J]. Food Science and Technology. 2000, (1): $24 \sim 25$.

[15] SHI C H, DAI Y, XU X L, et al. The purification of polyphenol oxidase from tobacco [J]. Protein Expression and Purification, 2002, 24: 51 55. 